\title{
UNDERSTANDING THE ROLE OF ENVIRONMENTAL GOVERNANCE NETWORKS IN WATERSHED GOVERNANCE AND MANAGEMENT
}

\author{
JUDY STEWART ${ }^{1} \&$ MARY ELLEN TYLER ${ }^{2}$ \\ ${ }^{1}$ Canadian Institute of Resources Law, University of Calgary, Canada \\ ${ }^{2}$ Faculty of Environmental Design, University of Calgary, Canada
}

\begin{abstract}
The Bow River Basin Council (BRBC) functions as both an environmental governance network (EGN) and a bridging organization for watershed management in the Calgary region of southwestern Alberta, Canada. BRBC's structure and function are examined to understand its role in inter-jurisdictional, cross-sectoral watershed management. EGNs such as BRBC emerge in complex social-ecological systems, and influence policy development and municipal participation in watershed management activities, manage information flows, and close functional cross-scalar "gaps" in government policy and regulation. Self-selecting and voluntary, BRBC stakeholders reflect multiple and sometimes competing sectoral interests in water and watershed management. EGNs such as BRBC may be structured to function as bridging organizations, brokering between actors in the watershed to achieve common watershed management objectives. The BRBC performs valuable functions for social learning, co-creation of knowledge, and collaborative and adaptive watershed management planning. Reflexive legal processes may provide the necessary procedural mechanisms to legitimize BRBC's decision-making processes and co-created watershed management plans.

Keywords: environmental management, environmental governance networks, bridging organizations, social-ecological systems, reflexive legal processes.
\end{abstract}

\section{INTRODUCTION}

The Calgary Metropolitan Area is a semi-arid social-spatial region of approximately $17,000 \mathrm{~km}^{2}$ located in the Bow River Watershed (the Watershed) in southern Alberta, Canada (the Calgary Region) [1], [2]. The cumulative negative effects on the Watershed's ecosystem as a result of years of rapid population and economic growth in the oil and gas industry are of concern to the Government of Alberta (GOA), local municipalities and private stakeholders [1]-[6]. Water scarcity limits growth [1], [6]. Qualitative research and social network analysis conducted between 2014 and 2016 explored how municipalities in the Watershed were addressing cross-scalar intermunicipal environmental and watershed management issues through intermunicipal collaboration or as stakeholders participating in environmental governance networks (EGN) [4], [5].

In 1994, the GOA delegated responsibility for regulating land use development on private lands to municipalities through the Municipal Government Act [7]. However, the GOA retained ownership and jurisdiction for allocating water resources and controlling environmental pollution. This regulatory system created legal and institutional gaps at the watershed scale where no provincial or municipal environmental policy or law existed. Between 2008 and 2016, the GOA adopted the Land-use Framework [8] and the Alberta Land Stewardship Act [9] that provided for regional land use regulations in the form of "regional plans" at the major watershed-scale. In Alberta, there are seven major watersheds identified in the Water Act [10]. These are vast land masses that contain several distinct social-ecological subsystems. The Calgary Region and the Watershed are embedded within the extensive planning area for the South Saskatchewan Regional Plan 2014-2024 [11] that takes in most of southern Alberta. 
In 1992, the predecessor of the Bow River Basin Council (BRBC) [4], [6] was formed as a multi-sectoral advisory body to the GOA to address emerging water quality issues in the Watershed. Council members were originally appointed to BRBC by Order of the Minister of Environment [6]. BRBC's geo-political boundaries included the lands, the people and their complex, dynamic interactions in the Watershed. Over time, BRBC emerged as a voluntary, self-organizing and self-regulating multi-stakeholder EGN of self-appointed stakeholders from the GOA, municipalities, industry, academia, non-government organizations, and the public [6]. BRBC's network expands and contracts over time depending on the complexity of issues affecting sectoral interests in the Watershed [4], [6].

BRBC eventually formalized as a charitable society to address intermunicipal water quality and quantity, water scarcity, and watershed management issues not addressed by the GOA or municipalities [4]-[6]. In 2004, BRBC was recognized as Alberta's first Watershed Planning and Advisory Council (WPAC) in Alberta, and is an integral partner in implementing Water For Life: Alberta's Strategy for Sustainability (Water For Life) in the Watershed [12]. BRBC operates by consensus, and has no legal mandate to enforce any law or regulation.

This paper examines the role of BRBC as an emergent EGN in inter-jurisdictional and cross-sectoral watershed management in the context of Alberta's regulatory system and the Watershed. In the context of BRBC, concepts of governance, network governance and EGNs are discussed, highlighting differences between environmental regulation and environmental governance. The roles of BRBC in watershed governance and management are explored, along with the legitimacy of BRBC's decision-making processes to find solutions to watershed management problems, and implement the co-created watershed management plan. Finally, reflexive legal processes [13] are briefly introduced as emergent institutional adaptions that could legitimize BRBC's decision-making processes and the watershed management plan [14].

\section{THE CALGARY REGION AND WATERSHED ARE COMPLEX DYNAMIC SOCIAL-ECOLOGICAL SYSTEMS}

Society and the ecosystem in the Watershed are inextricably connected, creating a complex, dynamic social-ecological system (SES) in constant flux [2], [5]. Self-interested crosssectoral stakeholders interact and compete for scarce water resources in the semi-arid region, including ranchers, farmers, irrigation districts, oil and gas companies, forestry, other commercial and industrial sectors and urban development [1]-[5]. Human activities are an integral part of the SES and are becoming dominant as the human and ecological systems coevolve and co-regulate cross-scalar adaptions [2], [3]. Feedback between the social and ecological systems sometimes leads to rapid changes in both systems, for example the 2013 flood in the Watershed that caused excessive property damages in communities in the Calgary Region [6].

Sudden changes in Alberta's land use and water regulations have had negative unintended consequences on industry practices and how public and private resource users govern themselves in the Watershed. For example, after the 2013 flood policies in BRBC's watershed management plan, that promotes mitigation of floods and droughts through natural systems such as wetland and riparian land conservation, was ignored by the GOA. Laws were rapidly enacted to regulate municipal development in floodways as part of crisis flood management. Hard infrastructure projects such as bank armoring and dry dams were rapidly introduced [6].

The dynamic nature of the SES in the Watershed is at odds with Alberta's regulatory system framed around scientific models and theories of long term certainty and predictability 
of water supply, and flood and drought regimes. Policy and information gaps about water and watershed management continue to emerge over time. Lags exist in response time between changes in fixed policy and regulatory regimes and dynamic SES [15]. Policy lags continue in the Watershed during periods of rapid population and economic growth, especially regarding management of wetlands and riparian lands adjacent to rivers and tributaries [5], [6].

SES are inherently difficult to govern due to uncertainties, dynamics, natural variations because ecosystems do not respect geo-political boundaries [16]. Alberta's regulatory regime attempts to govern and manage ecosystems through such boundaries and GOA departmental silos [2]-[4], and has been ineffective in managing sudden transboundary and transjurisdictional issues, such as floods and droughts. Social-ecological interdependencies are not easily managed through environmental regulation through GOA departments because of lack of integration, and because laws are generally slow to change. The science that informs legal and institutional change may not be what is needed to manage adaptions in any particular SES. Traditional approaches to law reform or scientific analysis take too long to inform decision-makers [16] during sudden events.

Society and the institutional arrangements to govern human interactions in the Watershed are generally "shocked" by sudden events leading to intense periods of human intervention to overcome impacts, and this is still occurring in the Watershed following the 2013 flood. A new GOA agency was rapidly created to fund and integrate projects for flood and drought mitigation [17]. Similarly, cumulative land use change in the Watershed has resulted in systemic loss of ecosystem resilience though regime shifts accelerated by rapid growth and policy changes affecting the allocation and use of water [4]-[6]. In turn, social and political change has compounded water quality degradation and loss of habitat and biodiversity [4][6]. The interrelationships and reciprocal impact within the SES need to be better understood to better inform Alberta's environmental policy and law [18]-[22].

\section{THE DIFFERENCES BETWEEN GOVERNANCE AND ENVIRONMENTAL REGULATION, AND EMERGENCE OF BRBC AS AN EGN IN THE WATERSHED}

Government enacted environmental laws and regulation and environmental governance refer to very different social-political processes in the Watershed. Environmental regulation by various levels of government in Alberta reflects the British common-law tradition, and is therefore authority-based with prescribed sanctions for non-compliance [4].

Scott and Trubek [23] compared traditional conceptions of formal and substantive laws as the unitary sources of authority for action. to governance systems that require dispersal of authority or power sharing among self-interested stakeholders. Unlike in regulatory hierarchies that use formal and substantive laws and court systems to ensure accountability, stakeholders involved in governance account to one another through trust building, peer influence, and persuasion [23].

Environmental governance systems rely on the continuous generation of new knowledge and policy and regulatory adaptions. Governance is necessarily dynamic, and evolves over time, while substantive laws and regulations may take considerable time to enact, amend or repeal [23]. Environmental regulations may also come into force rapidly in response to a sudden perturbation in the SES [4], such as the 2013 flood in the Watershed. However, environmental regulation and environmental governance systems are not mutually exclusive forms of governing. Governments participate in governance by imposing flexible rules based on scientifically determined standards that are implemented through a variety of mechanisms [23]. 
Governance processes often evolve from government command and control structures to various types of collaborative institutional arrangements within civil society that provide more flexibility at various spatial scales [24]. The legal system is also adapting and "reflexive legal processes" are evolving to support new social-political forms of governing [25], [26].

The concept of governance is not new in the social sciences [27], but governance processes continue to evolve. Building on the work of Stoker [28], and others, Biermann [29] defined governance as "notions of self-regulation by societal actors, or private-public cooperation in the solving of societal problems, and of new forms of multilevel policy". In Canada, Paquet [30] found that governance is an emergent phenomenon best understood as a pattern of relationships among societal actors that emerges when people connect to address shared social, economic or environmental problems that are not effectively or equitably addressed through the existing political-legal system [25], [31].

Kooiman [32], [33] noted that new social-political arrangements for governing have emerged due to increasing social complexity. When faced with complexity and uncertainty inherent in dynamic SES, environmental regulatory systems such as Alberta's regulatory regime, that focus on individual property rights and market-based instruments to allocate and manage natural resources may become ineffective or have unintended consequences, such as resource depletion and inequitable resource distribution [25], [34]-[36]. One law or regulation at any level of government does not address social-ecological interdependencies [37]. As a result, networks of affected stakeholders voluntarily self-organize to identify shared resource management issues and prevent resource degradation. Through collaborative processes, they redistribute scarce supplies of resources in a more equitable manner [4], [5], [31], [34]-[36].

Van Vliet [38] provided four identifying characteristics of EGNs: first, the social, economic or environmental problems they try to solve are complex; second, network actors are interdependent; third, the actors engage in negotiations or game-like processes to further their own interests; and, last, network actors learn from one another. Van Vliet [38] explained that EGNs are necessary institutional arrangements to provide critical governing capacity for responding to environmental degradation because complexity and dynamics in SES limit the capacity of unilateral government intervention through substantive laws [38].

Ostrom [34]-[36] recognized that economics were only one aspect of complex, social interactions when common pool resources that everyone relied upon for survival were at stake. Ostrom [34] compared the effectiveness of social exchanges based on family ties, culture, and common resource management values with the effectiveness of a rights-based approach and purely economic transactions. She proposed that self-organizing and selfregulating social-political arrangements enabled actors to rapidly respond to unpredictable and sudden changes in supplies of resources, making social connections critical to support traditional western environmental regulatory systems. Other governance researchers [39][41] have suggested that governance and management of scarce common-pool resources can be best accomplished through informal multi-actor networks engaged in collaboration, trustbuilding, social learning, and co-creation of knowledge. These informal governance processes are critical for negotiating complex trade-offs and ensuring equitable allocation of resources during periods of scarcity. In a similar context, the BRBC's governance processes emerged gradually in the Watershed, and not because of changes to substantive laws and regulations. Instead, stakeholders reached collective agreement about management issues and desired outcomes using collaboration and trust-building, co-generation of knowledge, and social learning to co-create and implement BRBC's watershed management plan [4]-[6].

BRBC's gradual emergence as an EGN in the Watershed reflects van Vliet's identifying characteristics as well as Breuillard's [37] finding that consultation and negotiation among 
affected stakeholders is needed to address complexity in SES. He recommended conflict prevention and place-based negotiations among affected stakeholders rather than unilateral rule-making and enforcement by government, and proposed a governance model that relied on governments to frame fair and equitable allocation among affected stakeholders. He suggested that voluntary self-organizing and self-regulating EGNs were necessary supports to government regulation. Pomeroy [42] essentially agreed, and added that government actions through supportive legislation, policies and authority structures are required to clarify jurisdiction and control decision-making processes within EGNs, and these legal structures in turn provide legitimacy to decisions reached by self-appointed stakeholders. EGN decision-making processes that respect property rights and established rules are accepted by all parties at the table [42].

BRBC also reflects Stoker's [28] five governance principles. GOA representatives participate in BRBC, steer and guide governance processes, and provide access to emergent tools and techniques for improving watershed management. BRBC's actions are consistent with Alberta's existing policy, regulatory and institutional framework, but BRBC's governance processes do not rely on the authority or sanctions of government. Instead, actors in BRBC are autonomous and self-governing, with consensus decision-making the norm [4], [5]. The EGN's boundaries and jurisdiction for tackling complex social and economic issues in the Watershed are dynamic, although power dependencies are respected between stakeholders. Stakeholders cooperate in implementing watershed management strategies that reflect shared community values [6]. BRBC stakeholders agree to achieve a balance between any conflicting management values that do arise in order to achieve desired outcomes that everyone can support [6].

While differences between concepts of environmental regulation and environmental governance may seem subtle, BRBC governance processes illustrate how governance differs considerably from government regulation. These distinctions are highlighted in Table 1 below.

Table 1: Key differences between government regulation and governance [4].

\begin{tabular}{|l|l|}
\hline Government regulation & Governance \\
\hline State actors and government & $\begin{array}{l}\text { Government, industry, non-government } \\
\text { organizations, public, etc. }\end{array}$ \\
\hline Government authorizes & Government participates, steers and guides \\
\hline Command and control regulation & Collaboration and negotiations between actors \\
\hline Minimal actors/administrators & Many actors/stakeholders \\
\hline Homogenous information & Heterogeneous information \\
\hline One size fits all & Different jurisdictional and spatial scales \\
\hline Knowledge flows from the top down & Knowledge flows between actors \\
\hline Predicated on existing knowledge & $\begin{array}{l}\text { Emphasizes continuous generation of } \\
\text { knowledge }\end{array}$ \\
\hline Change is slow & Dynamic, evolving, iterative processes \\
\hline Static management plans/policies & Adaptive co-management plans \\
\hline Plans takes years to change & Plans respond to system feedback - iterative \\
\hline
\end{tabular}

4 THE ROLES OF BRBC IN NETWORK GOVERNANCE IN THE WATERSHED Bulkeley [43] proposed that EGNs create a new "sphere of authority" that functions in network terms through social ties, individual commitment, and peer influence. Building on network theory and social network analysis [44], [45], and network governance theory [46], 
Newig et al. [47] referred to these new spheres of authority as governance networks engaged in "network governance". Since 1992, BRBC has been an EGN involved in network governance in the Watershed [4]-[6].

BRBC performs four distinct roles in network governance consistent with the literature [43], [47]. First, BRBC integrates government and civil society to better govern complex, dynamic SES for a public purpose. BRBC is driven to achieve a public purpose for the greater public good because the well-being of all actors can only be improved through collective intervention in the Watershed [43], [47]. Representatives from GOA and municipal government recognize the public purpose and voluntarily participate in BRBC contributing resources, data, and knowledge in support of EGN governance processes [4]-[6].

Second, BRBC is a bridging organization, connecting stakeholders in the Watershed who would otherwise not be connected [4], [5], [40], [41]. BRBC's boundaries are aligned with geo-political boundaries in the Watershed, including several distinct and fully functioning subcomponents operating at different scales, including watershed stewardship groups (WSG) that govern and manage human interactions in tributaries to the Bow River [6]. Network actors in WSG also collaborate voluntarily with no legal mandate, but with strong network ties to BRBC [6]. BRBC also connects eighteen municipal governments in the Watershed, and influences increased municipal participation in watershed management activities [4]-[6]. Through information sharing and submissions to the GOA and municipalities, BRBC often "bridges" and integrates policy and regulatory gaps between the different levels of government in response to feedback in the system [4]-[6], [13].

Network structure is important for rapid diffusion of information, values and norms [47]. Networks with central cores of actors with strong ties and weak ties to actors in the periphery of the network are more conducive to diffusion and social learning processes [47]. Social networks and the degree of collaboration, communication and social learning among actors in the periphery of the network are the keys to the success of governance network processes [21], [24], [39]-[41]. Using social network theory, mapping and analysis [48], Stewart [4] demonstrated that BRBC's network, with a strong, dense core of actors connected to the wider community through bridging actors at the network's periphery, was structured to promote social learning and rapid diffusion of knowledge and norms into the wider polity.

Third, BRBC provides opportunities for information sharing and social learning, cocreation of knowledge, and watershed management planning. Through quarterly educational meetings and workshops, BRBC shares information about watershed management strategies, and through subcommittee work stakeholders have co-created State of the Basin Reports and the watershed management plan [6]. The plan has no legal status with provincial or municipal land-use decision makers, but is voluntarily implemented reflecting strong social contracts between network actors.

Finally, BRBC is structured and functions as a broker of knowledge, values, power, and influence in the Watershed [4]-[6]. Brokerage roles arise through opportunities to implement Water For Life, and to co-create and amend the watershed management plan through consensus decision-making processes informed by defensible scientific study [6]. The plan is a living document with objectives and strategies to help stakeholders manage activities and interactions in the Watershed to sustain water quantity, water quality and watershed resiliency. BRBC's plan is also acknowledged by the GOA in the South Saskatchewan Regional Plan 2014-2024.

In 2016, Stewart [4] identified thirteen municipalities in the Watershed that were members of BRBC, and these municipalities (along with five others in the Watershed) collectively formed an identifiable EGN distinct from BRBC. Most of these eighteen municipalities were voluntarily engaging in several watershed management activities, while participating in 
regional scale land use planning, social learning, co-creation of knowledge, joint infrastructure development and funding for potable water, wastewater, transportation systems and economic development [4], [5]. Stewart [4] demonstrated that BRBC influenced increased municipal participation in watershed management activities in the Watershed by connecting municipalities with stakeholders who would otherwise not be connected, developing trusting relationships among them through collaborative problem solving processes, and engaging them in watershed management plan implementation [5]. While most municipalities voluntarily implemented the watershed management plan, others questioned the plan's legitimacy. Understandably, BRBC may appear to lack "democratic anchorage", as explained by Fotel et al. [49].

\section{THE LEGITIMACY OF THE WATERSHED MANAGEMENT PLAN}

BRBC's watershed management plan does not replace the formal government regulatory system for diversion and use of water or for regulating water pollution, but simply augments the regulatory system [6], [50], [51]. Researchers in Australia [50], New Zealand [51] and the United States [52] who have studied institutional frameworks for developing collaborative and adaptive watershed management plans caution that to be considered legitimate and successfully adopted and implemented by stakeholders, such plans must be grounded in substantive regulatory systems and reflect the rule of law [50]-[52]. Watson [53] explains that the "rule of law" requires that "every man should be governed by the law in their individual conduct as well as the government". Voluntary networks of stakeholders involved in governance processes must also meet "requirements for the assurance of legality" [53].

Sandström et al. [54] studied the "impact of pre-existing structures, social networks and governance strategies" on the legitimacy of co-management processes in five coastal and marine areas in Sweden. They tested the legitimacy of network governance strategies for managing network structure, network substance, and network processes, and concluded that four strategies affect stakeholder acceptance of co-management processes. These are strategies to influence the diversity of actors involved; strategies aiming to influence the involvement and commitment of relevant government representatives; strategies to (re)frame the management process, so as to align with stakeholder goals and/or pre-existing organizational structures; and strategies to facilitate stakeholder interactions through organizational arrangements and process design. BRBC employs the above strategies, and stakeholders do not challenge the legitimacy of BRBC's consensus decision making processes [4]. BRBC's governance processes also align with Fotel et al.'s [49] four criteria for determining democratic anchorage, as illustrated in Table 2 below. BRBC is not controlled by elected representatives from the GOA and local municipalities. However each Director on BRBC's Board of Directors is elected from within the sector he or she represents. For example, the GOA representative on the Board of Directors is elected from among several GOA departments and agencies that participate in BRBC.

Table 2: Fotel et al.'s [49] democratic anchorage criteria applied in BRBC [4].

\begin{tabular}{|l|l|}
\hline Democratic anchorage criteria & BRBC \\
\hline Controlled by democratically elected politician & NO \\
\hline Represent the membership basis of participating groups and organizations & YES \\
\hline Accountable to a territorially defined citizenry & YES \\
\hline $\begin{array}{l}\text { Facilitate interaction in accordance with a commonly accepted democratic } \\
\text { grammar of conduct }\end{array}$ & YES \\
\hline
\end{tabular}


While BRBC is a voluntary social-political arrangement, it is a formalized legal entity constituted under Alberta laws with requirements for Annual General Meetings with its membership, and annual reporting as a charitable society. It is accountable to its membership and the broader polity [4], [6]. The watershed management plan is a justifiably accurate presentation of shared watershed management values held by all the EGN members [4], [6]. Decisions made by the Board of Directors are accepted as legitimate by the broader membership, the GOA and municipal governments in the Watershed.

\section{THE CO-EMERGENCE OF SUPPORTIVE REFLEXIVE LEGAL PROCESSES}

Both Teubner [55] and Luhmann [56], [57] theorized that law is a dynamic subsystem of society, and responsive to feedback in the highly differentiated social system. Teubner [55] concluded that society has become disenchanted with goals, institutional structures, and performance of the regulatory state, and identified that the legal system was evolving from legal formalism and substantive legal processes and adapting to emergent needs of society. Teubner [55] coined "reflexive law" as a responsive evolutionary stage of the legal system, and proposed that a reflexive legal system would be more procedural than substantive in nature.

According to Fiorino [25], reflexive legal processes create incentives and procedures to induce people to continually reflect upon and assess their own behaviours and gradually adapt to changing social norms and objectives, for example creating less pollution or protecting endangered species. Lobel [26] shared this understanding of reflexive legal processes in the context of the new environmental governance model emerging in the United States. Stewart [4], [13] proposed several reflexive legal processes identified by Teubner [55], Fiorino [25], and Lobel [26] that could anchor BRBC and the co-created watershed management plan in necessary stakeholder acceptance and democratic legitimacy. Stewart [4] suggested that the GOA establish the following reflexive legal processes for BRBC in its role as a bridging organization in the Watershed: 1) regulate its design and internal governance to ensure democratic anchorage and appropriate self-regulation and reporting protocols; 2) officially recognize the value of $\mathrm{BRBC}$ by requiring that the co-created watershed management plan be considered by provincial and municipal land use decision-makers; 3) delegate some provincial and municipal powers to $\mathrm{BRBC}$ for watershed management at both local and regional scales; and 4), as proposed by Lobel [26] introduce policy learning opportunities to be explored through bridging processes, such as negotiated rule-making, audited selfregulation, performance based rules, decentralized and dynamic problem solving, disclosure regimes, and coordinated information collection.

\section{CONCLUSIONS}

Watershed governance and management requires collaboration among affected stakeholders from government and non-government sectors. New environmental policy and reflexive legal processes are needed to legitimize and sustain these collaborations and ensure that the state of the Watershed is kept within desired and scientifically supported bounds. In the Calgary Region and the Watershed these bounds are articulated in policy in the South Saskatchewan Regional Plan 2014-2024 and supporting resource management frameworks.

Watershed governance and management cannot occur in a regulatory vacuum. BRBC's governance functions are aligned with Alberta's established environmental regulatory systems and municipal land use planning as prescribed in the Municipal Government Act. As a WPAC under Water For Life, the GOA has recognized that BRBC's governance functions augment and support the regulatory system. 
While BRBC does not have legislative authority to achieve desired outcomes or enforce stakeholder implementation of the co-created watershed management plan, the ENG performs four valuable roles in watershed governance in the Watershed. BRBC integrates government and civil society to better govern the Watershed; connects stakeholders who may otherwise not be connected; provides opportunities for information sharing and learning, cocreation of knowledge, and watershed management planning; and, finally, brokers knowledge, values, power, and influence. In its advisory role, BRBC is a critical partner to the GOA and influences increased municipal participation in watershed management activities in the Watershed.

Reflexive legal processes are co-evolving with governance institutions such as BRBC. These legal-political constructs and institutional adaptions have emerged at the same time as EGNs in our global society. If implemented by the GOA, four suggested reflexive legal processes might further legitimize $\mathrm{BRBC}$ and the co-created watershed management plan.

\section{REFERENCES}

[1] Tyler, M.E. et al., Ecological Infrastructure in the Calgary Region "What We Know Now" Final Report. Prepared for the Calgary Regional Partnership, Calgary, AB, 2008.

[2] Tyler, M.E. \& Quinn, M., A social-spatial approach to ecological governance. International Journal of Interdisciplinary Social Sciences, 5(6), pp. 73-86, 2010.

[3] Tyler, M.E. \& Quinn, M., Identifying social-ecological couplings for regional sustainability in a rapidly urbanizing water-limited area of western Canada. Wessex Sustainability Development and Planning VI, WIT Press: Southampton and Boston, pp. 175-191, 2013.

[4] Stewart, J., A reflexive legal framework for bridging organizations in regional environmental governance and management. PhD thesis, University of Calgary, 2016.

[5] Stewart, J. \& Tyler, M.E., Bridging organizations and strategic bridging functions in environmental governance and management. International Journal of Water Resources Development, pp. 1-24, 2017.

[6] Stewart, J. \& Bennett, M., Integrated watershed management in the Bow River Basin, Alberta: Experiences, challenges, and lessons learned. International Journal of Water Resources Development, 33(3), pp. 458-472, 2017.

[7] Government of Alberta, Municipal Government Act, R.S.A. 2000, c.M-26. www.qp.alberta.ca/documents/Acts/m26.pdf. Accessed on: 2 Oct. 2018.

[8] Government of Alberta, Land-use Framework. www.landuse.alberta.ca/LandUse\%20 Documents/Land-use\%20Framework\%20-\%202008-12.pdf. Accessed on: 2 Oct. 2018.

[9] Government of Alberta, Alberta Land Stewardship Act, S.A. 2009, c. A-26.8. www.qp.alberta.ca/documents/Acts/A26P8.pdf. Accessed on: 2 Oct. 2018.

[10] Government of Alberta, Water Act, R.S.A. c.W-6. www.qp.alberta.ca/documents/Acts/w03.pdf. Accessed on: 2 Oct. 2018.

[11] Government of Alberta, South Saskatchewan Regional Plan 2014-2024. https://open.alberta.ca/dataset/460ac866-4416-4d77-a25a-a02fab85a6ec/resource/ 8261ce03-aa0f-4621-8e2d-c610a72ac37c/download/south-saskatchewan-regionalplan-2014-2024-february-2017.pdf. Accessed on: 2 Oct. 2018.

[12] Government of Alberta, Water For Life: Alberta's Strategy for Sustainability. https:/open.alberta.ca/dataset/77189444-7456-47f7-944c-085272b1a79c/resource/ 17c41dc3-1692-4cf9-b931-2892c57a62b1/download/2003-water-life-albertasstrategy-sustainability-november-2003.pdf. Accessed on: 2 Oct. 2018. 
[13] Stewart, J., Reflexive approaches to lawmaking to legitimize environmental bridging organizations in the Calgary region. Journal of Environmental Law and Practice, 31(1), pp. 37-77, 2017.

[14] Bow River Basin Council, Bow Basin Watershed Management Plan 2012. http://brbc.ab.ca/index.php/resources/bbwmp. Accessed on: 18 Oct. 2018.

[15] Westley, F., Carpenter, S.R., Brock, W.A., Holling, C.S. \& Gunderson, L.H., Why systems of people and nature are not just social and ecological systems. Panarchy. Understanding Transformations in Human and Natural Systems, eds L.H. Gunderson \& C.S. Holling, Island Press: Washington, DC, 2002.

[16] Bodin, O. \& Crona, B.I., The role of social networks in natural resource governance: What relational patterns make a difference? Global Environmental Change, 19, pp. 366-374, 2009.

[17] Government of Alberta, Watershed resiliency and restoration program. http://aep.alberta.ca/water/programs-and-services/watershed-resiliency-andrestoration-program/default.aspx. Accessed on: 25 Oct. 2018.

[18] Redman, C.L., Grove, J.M. \& Kuby, L.H., Integrating social science into the Long Term Ecological Research (LTER) network: Social dimensions of ecological change and ecological dimensions of social change. Ecosystems, 7, pp. 161-171, 2004.

[19] Ebbesson, J., The rule of law in governance of complex social-ecological change. Global Environmental Change, 2010.

[20] Ebbesson, J. \& Hey, E., Introduction: Where in law is social-ecological resilience? Ecology and Society, 18(3), 2013.

[21] Berkes, F. \& Colding, J. eds, Navigating Social-Ecological Systems: Building Resilience for Complexity and Change. Cambridge University Press: Cambridge, 2003.

[22] Janssen, M.A. et al., Toward a network perspective of the study of resilience in socialecological systems. Ecology and Society, 1(1), p. 15, 2006.

[23] Scott, J. \& Trubek, D.M., Mind the gap: Law and new approaches to governance in the European Union. European Law Journal, 8(1), pp. 1-18, 2002.

[24] Crona, B. \& Hubacek, K., The right connections: How do social networks lubricate the machinery of natural resource governance? Ecology and Society, 15(4), p. 18, 2010.

[25] Fiorino, D., The New Environmental Regulation, Massachusetts Institute of Technology: Massachusetts, 2006.

[26] Lobel, O., The renew deal: The fall of regulation and the rise of governance in contemporary legal thought. Minnesota Law Review, 89, pp. 262-390, 2004.

[27] Bevir. M. ed., The SAGE Handbook of Governance, Sage: London, 2011.

[28] Stoker, G., Governance as theory: Five propositions. International Social Science Journal, 50, pp. 17-28, 1998.

[29] Biermann, F., Global Environmental Governance. Conceptualization and Examples. Global Governance Working Paper No. 12, Amsterdam, Berlin, Oldenburg, Postdam: The Global Governance Project. www.glogov.org/images/doc/WP12.pdf. Accessed on: 2 Oct. 2018.

[30] Paquet, G., Governance Through Social Learning, University of Ottawa Press: Ottawa, p. 12, 1999.

[31] Kooiman, J., Bavinck, M., Chuenpagdee, R., Mahon, R. \& Pullin, R., Interactive governance and governability: An introduction. The Journal of Transdisciplinary Environmental Studies, 7(1), pp. 1-11, 2008. 
[32] Kooiman, J. ed., Modern Governance: New Government-Society Interactions, SAGE Publications: London, p. 2, 1993.

[33] Kooiman, J., Societal governance: Levels, modes and orders of social-political interaction. Debating Governance, Authority, Steering and Democracy, ed. J. Pierre, Oxford University Press: Oxford, 2000.

[34] Ostrom, E., Governing the Commons: The Evolution of Institutions for Collective Action, Cambridge University Press: New York, 1990.

[35] Ostrom, E., Understanding Institutional Diversity, Princeton University Press: Princeton, NJ, 2005.

[36] Ostrom, E., A general framework for analyzing sustainability of social-ecological systems. Science, 325, pp. 419-422, 2009.

[37] Breuillard, M., Dynamics and room to maneuver in governance: The Channel Tunnel decision in France and Britain. Modern Governance: New Government-Society Interactions, ed. J. Kooiman, SAGE Publications: London, p. 111, 1993.

[38] van Vliet, M., Environmental regulation of business: Options and constraints for communicative governance. Modern Governance: New Government-Society Interactions, ed. J. Kooiman, SAGE Publications: London, pp. 106-107, 1993.

[39] Crona, B.I. \& Parker, J.N., Learning in support of governance: theories, methods, and a framework to assess how bridging organizations contribute to adaptive resource governance. Ecology and Society, 17(1), 2012.

[40] Rathwell, K.J. \& Peterson, G.D., Connecting social networks with ecosystem services for watershed governance: A social-ecological network perspective highlights the critical role of bridging organizations. Ecology and Society, 17(2), 2012.

[41] Bodin, O. \& Prell, C. eds, Social Networks and Natural Resource Management: Uncovering the Social Fabric of Environmental Governance, Cambridge University Press: New York, 2011.

[42] Pomeroy, R., Conditions for successful fisheries and coastal resources comanagement: Lessons learned in Asia, Africa, and the wider Caribbean. Adaptive Comanagement: Collaboration, Learning, and Multi-Level Governance, eds D. Armitage, F. Berkes \& N. Doubleday, University of British Columbia Press: Vancouver, p. 175, 2007.

[43] Bulkeley, H., Reconfiguring environmental governance: Towards a politics of scales and networks. Political Geography, 24, pp. 875-890, 2005.

[44] Granovetter, M., The strength of weak ties. American Journal of Sociology, 78, pp. 1360-1380, 1973.

[45] Wasserman, S. \& Faust, K., Social Network Analysis: Methods and Applications, Cambridge University Press: Cambridge, 1994.

[46] Torfing, J., Governance network theory: Towards a second generation. European Political Science, 4, pp. 305-315, 2005.

[47] Newig, J., Gunther, D. \& Pahl-Wostl, C., Synapses in the network: Learning in governance networks in the context of environmental management. Ecology and Society, 15(4), pp. 1-3, 2010.

[48] de Nooy, W., Mrvar, A. \& Batagelj, V., Exploratory Social Network Analysis with Pajek, 2nd edn, Cambridge University Press: Cambridge, 2011.

[49] Fotel, T., Sorensen, E. \& Torfing, J., Measuring the democratic anchorage of governance networks: The case of the Femern Belt Forum. Working Paper 2008/1. Center for Democratic Network Governance, Roskilde, Denmark, pp. 1-31, 2008. 
[50] Holley, C. \& Sinclair, D., A new water policy option for Australia? Collaborative water governance, compliance and enforcement and audited self-management. The Australasian Journal of Natural Resources Law and Policy, 17(2), pp. 189-216, 2014.

[51] Jenkins, B.R., Water Management in New Zealand's Canterbury Region: A Sustainability Framework, Springer: Netherlands, 2018.

[52] Ruhl, J.B. \& Fischman, R.L., Adaptive management in the courts. Minnesota Law Review, 95, p. 470, 2010.

[53] Watson, J., You don't know what you've got 'til it's gone: The rule of law in Canada - Part II. Alberta Law Review, 52(4), pp. 949-988, 2015.

[54] Sandström, A., Crona, B. \& Bodin, Ö., Legitimacy in co-management: The impact of preexisting structures, social networks and governance strategies. Environmental Policy and Governance, 24(1), pp. 61-63, 2014.

[55] Teubner, G., Substantive and reflexive elements in modern law. Law \& Society Review, 17(2), pp. 239-286, 1983.

[56] Luhmann, N., The Differentiation of Society, Columbia University Press: New York, 1982.

[57] Luhmann, N., Law as a Social System, Oxford University Press: New York, 2004. 